\title{
Comparison of the effects of treadmill and ergocycle exercise on the functional capacity and quality of life of patients with chronic obstructive pulmonary disease
}

\author{
Helena Turnip, ${ }^{1}$ Anita Ratnawati, ${ }^{2}$ Angela Tulaar, ${ }^{1}$ Faisal Yunus, ${ }^{3}$ Aria Kekalih ${ }^{4}$ \\ ${ }^{1}$ Department of Physical Medicine and Rehabilitation, Faculty of Medicine, Universitas Indonesia, Jakarta, Indonesia \\ ${ }^{2}$ Installation of Physical Medicine and Rehabilitation, RSU Persahabatan, Jakarta, Indonesia \\ ${ }^{3}$ Department of Pulmonology, RSU Persahabatan, Jakarta, Indonesia \\ ${ }^{4}$ Department of Community Medicine, Faculty of Medicine, Universitas Indonesia, Jakarta, Indonesia
}

\begin{abstract}
Abstrak
Latar belakang: Latihan fisik diharapkan dapat memperbaiki kapasitas fungsional dan kualitas hidup pada penderita penyakit paru obstruktifkronik (PPOK). Penelitian ini bertujuan untuk menilai perbedaan antara latihan jentera dan sepeda statis terhadap perubahan kapasitas fungsional dan kualitas hidup pada pasien PPOK stabil.
\end{abstract}

Metode: Penelitian eksperimental dengan pengamatan berulang sebelum dan sesudah perlakuan dilakukan pada 44 subjek dengan PPOK yang datang ke poli Rehabilitasi Medik RS Persahabatan. Latihan sepeda statis dilakukan pada 22 subjek dan latihan jentera pada 22 subjek. Kapasitas fungsional dinilai dengan metode uji jalan 6 menit (UJ6M) dengan mengukur jarak berjalan dalam lintasan 30 meter bolak-balik selama 6 menit, dilakukan minggu I, V dan IX. Penilaian kualitas hidup diukur menggunakan kuesioner St. George's Respiratory Questionnaire (SGRQ) pada minggu I dan IX dengan mengisi sendiri kuesioner yang diberikan kepada subjek. Program latihan dilakukan selama 8 minggu dengan dosis latihan berdasarkan hasil uji latih pada minggu $I$.

Hasil: Latihan jentera dan sepeda statis menghasilkan perbaikan signifikan dalam hasil uji jalan 6 menit dan $S G R Q$ sejak minggu I sampai $I X$. Latihan jentera lebih baik dalam meningkatkan jarak tempuh jalan 6 menit dibandingkan sepeda statis secara konsisten pada minggu I-V, V-IX dan I-IX $(p<0,001)$. Untuk nilai SGRQ, hasil kedua latihan tidak berbeda signifikan.

Kesimpulan: Latihan jentera menghasilkan peningkatan kapasitas fungsional yang lebih besar dan berbeda bermakna dibandingkan kelompok latihan sepeda statis pada subjek PPOK stabil. Sedangkan kualitas hidup tidak berbeda bermakna anara kedua jenis latihan.

\begin{abstract}
Background: Physical excercises are hoped to improve functional capacity and quality of life of patients with chronic obstructive pulmonary disease (COPD). This study is aimed to assess the differences between treadmill and ergocycle exercise on changes in functional capacity and quality of life in patients with stable COPD.
\end{abstract}

Methods: This is an experimental study with complete randomization and repeated pre- and post-intervention observation. The study was conducted on 44 subjects with COPD who were presented at Persahabatan Hospital, Medical Rehabilitation Clinic, consisting of 22 subjects undergoing ergocycle exercise and 22 subjects undergoing treadmill exercise test. Functional capacity was assessed by using the 6 minutes walking test (6 MWT) performed at week I, V and IX. Quality of life was measured using the St. George's Respiratory Questionnaire (SGRQ) at week I and IX. Training program was conducted for 8 weeks with exercise dosage based on the results of exercise test on week I.

Results: Treadmill and ergocycle exercise produce significant improvement in both the 6 MWT and SGRQ test since week I to IX. But in comparison, treadmill exercise improves 6 MWT distance better than ergocycle consistently at week I-V, V-IX and I-IX $(\mathrm{p}<0.001)$. For the SGRQ score, both exercises did not differ significantly.

Conclusion: Treadmill exercise is associated with significantly better improvement in functional capacity compared to ergocycle exercise in stable COPD subjects. Concerning quality of life, both exercises gave an equivalent improvement in stable COPD subjects.

Keywords: chronic obstructive pulmonary disease, ergocycle exercise, functional capacity, treadmill exercise, quality of life

pISSN: 0853-1773 • eISSN: 2252-8083 • http://dx.doi.org/10.13181/mji.v23i1.726 • Med J Indones. 2014;23:42-7

Correspondence author: Helena Turnip, helenaturnip@gmail.com

Copyright@2014 Authors. This is an open access article distributed under the terms of the Creative Commons Attribution-NonCommercial-ShareAlike 4.0 International License (http://creativecommons.org/licenses/by-nc-sa/4.0/), which permits unrestricted non-commercial use, distribution, and reproduction in any medium, provided the original author and source are properly cited. 
Chronic obstructive pulmonary disease (COPD) is one of the pulmonary disorders resulting in disability and mortality. COPD patients frequently experience progressive disabilities and handicaps leading to reduced exercise capacity. The deterioration of condition is initiated by long-term shortness of breath, eventually leading to physical deconditioning that impairs the functional status and quality of life of the patients.

Rehabilitation programs in COPD include reconditioning exercise aimed to increase physical capacity and ability to perform daily activities. Various types of exercise provided for COPD patients is aimed to improve cardiopulmonary endurance. The training is usually associated with exercises using large muscle groups, i.e. lower extremity muscles. Treadmill and ergocycle exercises are some of the reconditioning exercise program using large muscles of the lower extremities. ${ }^{1}$ To produce reconditioning which is appropriate with the aim of the exercise, treadmill and ergocycle exercise should be performed using specific training program, regarding that the subjects had already suffered from pulmonary function limitations. ${ }^{2.3}$

The patients are expected to perform measurable exercise with appropriate intensities. In this study, treadmill and ergocycle exercise were performed using the exercise intensity set according to the individual capacity of the patients. Training programs were provided to stable COPD patients and expected that continuous exercise should increase the physical capacity and build the motivations to exercise regularly, which in turn would improve their quality of life. The hypothesis of this study is that stable COPD patients who had treadmill exercise would show significant changes in functional capacity and quality of life compared to those with ergocycle exercise.

\section{METHODS}

This is an experimental study with simple random sampling and repeated observation, both prior and after the intervention, performed in the rehabilitation medicine clinic of Persahabatan Hospital during the period of October 2012 to June 2013. The subjects were allocated using simple random sampling using tables from the results of randomization in SPSS program.

\section{Recruitment and procedure}

The protocol of this study has been approved by Health Research Ethics Committee Faculty of Medicine,
Universitas Indonesia, Cipto Mangunkusumo Hospital. The subjects were outpatients who were diagnosed with stable COPD in the Pulmonology Clinic of Persahabatan Hospital in Jakarta, who had oxygen saturation of $\geq 90 \%$, men or women aged 55-80 year old, cooperative and capable of performing walking/cycling exercise, and willing to participate in the study by signing the informed consent. The exclusion criteria were those with heart disease, history of asthma, neuromusculosceletal disorder particularly in the lower extremities which impairs the walking function, suffering from cor pulmonale, cognitive disorder and who were using tracheostomy in place. Subjects who did not perform the treadmill or ergocycle exercise 4 times in a row or less than 2 times/week, or those who had exacerbation of their disease were dropped out from the study. The subjects who were dropped out could return to participate in the study 2 weeks later.

The subjects were randomly divided into treadmill or ergocycle groups. The training was conducted for 8 weeks with the frequency of 3 times a week. The study included 44 COPD subjects who visited the Medical Rehabilitation of Persahabatan Hospital, divided into 22 subjects allocated to ergocycle training and 22 subjects allocated to treadmill training. The assessment of functional capacity was performed using 6-minute walking test (6MWT) on week I, V, and IX by measuring the walking distance on a 30-meter lane back and forth for 6 minutes, with results values expressed in meters. The quality of life assessment was measured using St. George's Respiratory Questionnaire (SGRQ) performed on week I and IX by independent filling of the questionnaires given to the subjects. The questionnaire consisted of 76 questions divided into 3 components: symptom, activity, and impact. Training program was conducted for 8 weeks with exercise dosage based on the results of exercise test on week I. The estimation of ergocycle and treadmill training workload were based on The Cooper Clinic and Research Institute Fitness Series with some modifications. ${ }^{4}$

\section{Statistical analysis}

The increase in functional capacity, SGRQ prior to and after the intervention, was analyzed by paired t-test or Wilcoxon test. Comparisons between the two groups was performed by unpaired t-test or Mann- 
Whitney test for data with abnormal distribution. The $p$ value of $<0.05$ was taken as the limit of statistical significance. All data analysis was conducted using SPSS for Windows version 17.0.

\section{RESULTS}

This study included 44 COPD subjects divided in two groups, 22 in ergocycle group and 22 treadmill group. The subjects were dominated by men; only 2 women participated in the study. Statistically, there was no significant difference in sex, BMI, and degree of COPD in both groups (Table 1).

Most subjects were male (95.4\%); only $4.5 \%$ were females and they were allocated to the treadmill group. The body mass index (BMI) of the subjects

Table 1. Characteristics of subjects in the treadmill and ergocycle groups

\begin{tabular}{lccc}
\hline Characteristics & $\begin{array}{c}\text { Ergocycle } \\
\mathrm{n}(\%)\end{array}$ & $\begin{array}{c}\text { Treadmill } \\
\mathrm{n}(\%)\end{array}$ & $\begin{array}{c}\text { Total } \\
\mathrm{n}(\%)\end{array}$ \\
\hline Sex & & & \\
\hline Men & $22(52.4)$ & $20(47.6)$ & $42(95.4)$ \\
\hline Women & $0(0.0)$ & $2(100.0)$ & $2(4.5)$ \\
\hline BMI & & & \\
\hline Underweight & $3(60.0)$ & $2(40.0)$ & $5(11.4)$ \\
\hline Normal & $14(53.8)$ & $12(46.2)$ & $26(59.1)$ \\
\hline Overweight & $0(0.0)$ & $4(100.0)$ & $4(9.1)$ \\
\hline Obesity & $5(55.6)$ & $4(44.4)$ & $9(20.4)$ \\
\hline Degree of COPD & & & \\
\hline Mild & $2(9.1)$ & $4(18.2)$ & $7(15.9)$ \\
\hline Moderate & $11(50.0)$ & $10(45.4)$ & $21(47.7)$ \\
\hline Severe & $9(40.9)$ & $8(36.4)$ & $16(36.4)$ \\
\hline History of smoking & & & \\
\hline Yes & $22(56.4)$ & $17(43.6)$ & $39(88.6)$ \\
\hline No & $0(0.0)$ & $5(100.0)$ & $5(11.4)$ \\
\hline
\end{tabular}

were mostly categorized as normal body mass index (59.1\%) although 13 subjects had higher than normal proportion and 5 subjects were underweight. Most of the subjects referred from the Pulmonology Department who receive medical rehabilitation were diagnosed with moderate COPD (47.7\%); only $15.9 \%$ were diagnosed with mild COPD. Most of the COPD subjects were active smokers $(88.6 \%)$ and only a few were not smokers or passive smokers $(11.4 \%)$.

\section{Influence of aerobic training program on the changes of functional capacity.}

In figure 1, treadmill and ergocycle exercise is associated with a consistent increase in the functional capacity, obtained from the 6 MWT on Week 1 (6 MWT I), week 5 (6 MWT V) and week 9 (6 MWT IX). These results showed that the effects of these exercise were beneficial over time to increase the functional capacity during the 8 weeks of training.

Table 2 demonstrates the comparison between the difference of distance of 6 minutes walking test in treadmill and ergocycle groups along week I, V, and IX.

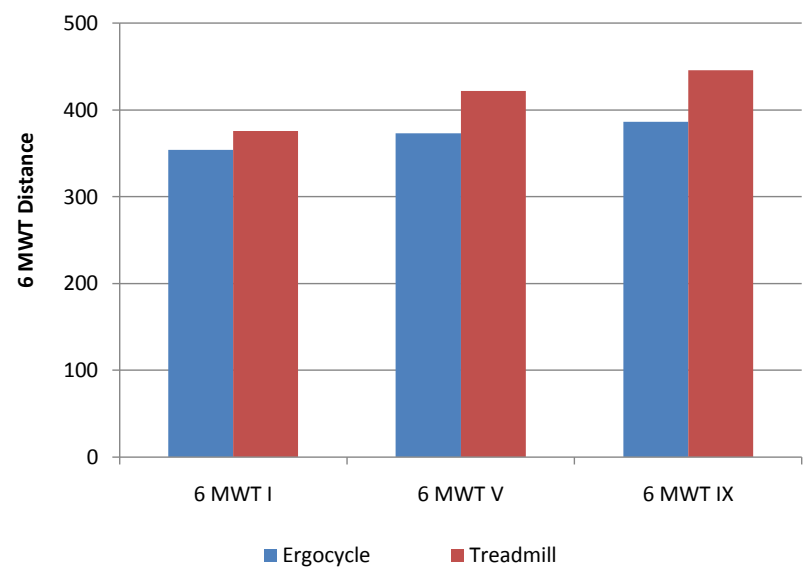

Figure 1. Changes of functional capacity between week I, week $\mathrm{V}$ and week IX in treadmill and ergocycle groups

Table 2. The difference of distance covered after 6 minute walking test ( $\triangle 6 \mathrm{MWT}$ ) on week I, V and IX between treadmill and ergocycle groups

\begin{tabular}{lcc}
\hline Periodes & $\begin{array}{c}\text { Ergocycle }(\mathrm{n}=22) \\
\text { mean } \pm \text { SD }\end{array}$ & $\begin{array}{c}\text { Treadmill }(\mathrm{n}=22) \\
\text { mean } \pm \text { SD }\end{array}$ \\
\hline Week IX - I, meter & $32.1(\mathrm{SD} 12.6)$ & $70.4(\mathrm{SD} 18.3)$ \\
Week IX - V, meter & $12.8(\mathrm{SD} 6.5)$ & $23.9(\mathrm{SD} 16.7)$ \\
Week V - I, meter & $19.2(\mathrm{SD} 9.9)$ & $46.4(\mathrm{SD} 14.4)$ \\
\hline
\end{tabular}




\section{Influence of aerobic training program on the changes of quality of life.}

Table 3 shows that each group only demonstrated significant changes of quality of life week I (before exercise) and after week IX of the training.

In table 4, the comparison of quality of life between week I and week IX in the treadmill and ergocycle groups for each domain did not demonstrate any significant differences.

\section{DISCUSSION}

In this study, the mean distance covered in 6 MWT on weeks I, II and III in the ergocycle exercise and treadmill exercise groups showed similarly significant changes $(p<0.001)$. It means that both exercise were associated with significant increase in functional capacities of these subjects as demonstrated by the ability to walk 6 minutes in these subjects through the $4^{\text {th }}$ week of training. The increase is progressive through the end of week 8 . The functional capacity in COPD based on the distance covered in 6 minutes of walking test demonstrated significant differences after performing 8 weeks of aerobic training. This is in accordance to the theory stating that 8 weeks of aerobic training may increase functional capacity in subjects with COPD.,3

Finnerty et $\mathrm{al}^{5}$ reported that the results of 6 MWT in the group who received rehabilitation program for 6 weeks were increased to 59 meters. Bendstrup et $\mathrm{al}^{6}$ reported the increased of distance of 79.8 meters in the intervention group and 21.6 meters in the control group $(\mathrm{p}<0.001)$. Lacase et $\mathrm{al}^{7}$ performed a meta-analysis on the COPD subjects who received rehabilitation program; the mean of distance covered on $6 \mathrm{MWT}$ was 55.7 meters. The study observed that the minimum clinically important difference (MCID) was 50 meters, while Redelmier et al., observed a 54 meters as the MCID. ${ }^{8}$ Guell in 2000 performed 6 MWTs in 30 COPD subjects who received pulmonary rehabilitation (exercise and chest physiotherapy) for 6 months compared to COPD without the pulmonary rehabilitation, and obtained increase in distance of 57 meters. $^{9}$

In our study, regarding the changes of functional capacity between the ergocycle and treadmill groups, there was a significant change in the increments of 6 MWT results from week I to week V, week I to Week IX and week V to week IX. This is in accordance with the theory that both types of aerobic exercise

Table 3. Changes in quality of life between week I and week IX in the ergocycle and treadmill group

\begin{tabular}{llcc}
\hline Type of exercise & Domains & $\begin{array}{c}\text { Week I } \\
\text { Median (range) }\end{array}$ & $\begin{array}{c}\text { Week IX } \\
\text { Median (range) }\end{array}$ \\
\hline Ergocycle & Symptoms & $364.3(236.9-483.8)$ & $224.3(159.8-298.9)$ \\
\hline & Activities & $538.5(207.0-824.2)$ & $282.1(0.0-432.7)$ \\
\hline Impacts & $812.5(76.6-1319.4)$ & $17.4(0.0-480.6)$ \\
\hline Treadmill & Total & $43.9(14.7-6-65.9)$ & $238.4(159.8-305.3)$ \\
\hline & Symptoms & $334.2(236.9-456.1)$ & $282.1(0.0-505.0)$ \\
\hline
\end{tabular}

Table 4. Comparison between the changes in quality of life between week I and IX in the ergocycle and treadmill groups

\begin{tabular}{lccc}
\hline Domain & Ergocycle & Treadmill & $p$ \\
\hline Symptoms & $-116.8($ SD 62.7) & $-106.2($ SD 59.8) & 0.572 \\
Activities & $-293.8(-666.0-(-71.4))$ & $-293.8(-428.9-(-72.1))$ & 0.539 \\
Impacts & $-664.8(-1032.9-(-76.6))$ & $-630.7(-1124.6-(-76.6))$ & 0.706 \\
Total & $-26.5(-45.1-(-6.3))$ & $-26.5(-39.1-(-8.2))$ & 0.879 \\
\hline
\end{tabular}


are beneficial to increase the functional capacity, as shown by the good results in the ergocycle and treadmill group, but treadmill gave a better result. The possible explanation of this difference may be due to the fact that treadmill is an exercise machine with regulated speed so the subjects should be able to maintain their balance and coordination during excercice. Meanwhile, the pedalling speed with ergocycle could be altered by the subjects despite the use of metronome, causing the inadequate efforts in training. Thus, it results in the lower functional capacity of subjects using ergocycle compared to treadmill.

In a study by Murray et $\mathrm{al}^{10}$ regarding the perception responses and physiology on treadmill and ergocycle exercise for COPD subjects, the value of $\mathrm{VO}_{2}$ was demonstrated to be significantly higher in the treadmill exercise. While Carter et $\mathrm{al}^{11}$ found that oxygen uptake was significantly higher increase of $\mathrm{VO}_{2}$ max after treadmill exercise compared to ergocycle. This is supported by Palange et $\mathrm{al},{ }^{12}$ who studied the ventilation and metabolic adaptation in walking and cycling for COPD subjects and explained that while walking, the muscles in the arms become active and become the source of neurogenic impulses to the respiration control center. On the contrary, the arms tend to be in a static position during cycling, thus they do not become the source of neurogenic impulses. A more stable position in cycling may support the shoulders and allow the accessory muscles to help the respiration. ${ }^{12}$

Sava et $\mathrm{al}^{13}$ studied the influence of obesity to the walking and cycling performance and the responses of pulmonary rehabilitation in COPD subjects and found that the 6 MWT results were increased significantly in both groups. However, the $6 \mathrm{MWT}$ values were still significantly lower in subjects with obesity. The walking performance of obese subjects were worse, but remains unaffected in cycling. Pulmonary rehabilitation provides some clinical benefits for subjects with COPD, but the benefit is much smaller in overweight and obese subjects. Therefore, coexistence of COPD and obesity will require a more comprehensive management consisting of aerobic training, diet and counseling. ${ }^{13}$

The quality of life was assessed by SGRQ questionnaire. Lower SGRQ level represents a better health condition (quality of life) of the subjects, while higher SGRQ level represents a worse health condition (quality of life). In a study by Yuarsa et a $1^{14}$ regarding the correlation between the quality of life and prognosis of COPD subjects using CAT, SGRQ and BODE in Persahabatan Hospital Jakarta, there was a weak correlation between the CAT questionnaire and SGRQ in assessing the quality of life for COPD patients $(r=$ 0.181). CAT questionnaire could not replace SGRQ in assessing the quality of life of COPD subjects because SGRQ was shown to be superior and was able to differentiate the quality of life, health status and severity of disease. ${ }^{14}$ SGRQ questionnaire could also be utilized to detect the response to medical and non-medical therapy, such as pulmonary rehabilitation. Minimum significant clinical change is represented by SGRQ score of $4 \%{ }^{6}$

SGRQ questionnaire has been adjusted to objectively assess the effects of disease on the daily lives of the patients. The assessment of quality of life as proposed by PW Jones was the influence of disease to daily lives. SGRQ questionnaire is more correlated with quality of life compared to lung physiology. ${ }^{15}$ Due to the progressiveness of the disease, COPD subjects often suffer from psychological and social disturbances. ${ }^{16}$ The prevalence of depression in COPD subjects is estimated $42 \%$. Other symptoms of depression, including feeling sad, unmotivated, guilty feeling, or helpless, or suicidal thoughts and psychomotor regression are often reported in subjects with COPD. Some factors that may cause depression include problems in daily activities and inability to work due to the progressivity of the disease. ${ }^{17}$ Lacase et $\mathrm{al}^{7}$ concluded that pulmonary rehabilitation would relieve shortness of breath and increase the ability to perform activities in COPD subjects, which eventually would increase the functional capacity and quality of life. Rehabilitation would increase maximum oxygen consumption and maximum work capacity, thus increasing the functional capacity and quality of life.

In this study, the changes found in the quality of life between the ergocycle and treadmill groups demonstrated a comparable benefit. This shows that both exercise types would result in subjectively similar significant results in COPD subjects. A theory stated that the energy requirement for respiratory efforts during rest was only $30 \%$ of total energy requirements. Therefore, the physical ability for COPD relieve as reflected in activities such as climbing stairs, walking, or performing daily activity would be very limited because the respiration process 
itself is already a burdensome workload for the body, which eventually causing COPD subjects to become inactive. ${ }^{18}$

In the comparison between the changes in quality of life between ergocycle and treadmill exercise group, there was no significant difference of both groups. It can be concluded that these types of exercise are similarly beneficial as aerobic exercise to increase the functional capacity and quality of life of COPD subjects. A possible explanation of these result is that the period of training was not sufficient to increase the quality of life subjectively between the ergocycle and treadmill. Although objectively, significant changes in quality of life was observed. Various factors should be considered in assessing quality of life of the subjects, including physical, emotional and general health aspects including pain, while this study only provide intervention for the physical aspects.

From this study, it could be concluded that treadmill exercise test resulted in a significantly greater increase in functional capacity compared to ergocycle test in stable COPD patients. While its influence on quality of life was not significantly different.

\section{Acknowledgment}

The authors would like to express appreciation for Esti Widyastuti, SST.Ft, a physiotherapist who assist to carry out this study.

\section{Conflict of interest}

The authors declare that this study is free of conflict of interest.

\section{REFERENCES}

1. Keputusan Menteri Kesehatan Republik Indonesia Nomor 1022/Menkes/SK/XI/2008. Tentang pedoman pengendalian penyakit paru obstruktif kronik. Departemen Kesehatan Republik Indonesia, 2008. p. 4-7. Indonesian.

2. Holtgrefe K, Glenn MT. Therapeutic exercise foundation and technique. In: Kisner C, Colby LA, editors. Principles of aerobic exercise, $5^{\text {th }}$ ed. Philadelphia: F.A. Davis Company; 2007. p. 231-49.

3. Cooper CB. Pulmonary disease: chronic obstructive pulmonary disease. In: Durstine JL, Moore GE, Painter
PL, Roberts SO, editors. ACSM'S exercise management for Persons with chronic disease and disability, $5^{\text {th }}$ ed. Champaign: Human Kinetics; 2009. p. 129-35.

4. Gordon NF. Breathing disorder your complete exercise guide (The cooper clinic and research institute fitness series). Champaign: Human Kinetics; 1993.

5. Finnerty JP, Keeping I, Bullough I, Jones J. The effectiveness of outpatient pulmonary rehabilitation in chronic lung disease: a randomized controlled trial. Chest. 2001;119(6):1705-10.

6. Bendstrup KE, Ingemann Jensen J, Holm S, Bengtsson B. Outpatient rehabilitation improves activities of daily living, quality of life and exercise tolerance in chronic obstructive pulmonary disease. Eur Respir J. 1997;10(12):2801-6.

7. Lacase Y, Wong E, Guyat GH, King D, Cook DJ. Goldstein RS. Meta-analysis of respiratory rehabilitation in chronic obstructive pulmonary disease. Lancet. 1996;348(9035):1115-9.

8. Redelmeier DA, Bayoumi AM, Goldstein RS, Guyatt GH. Interpreting small differences in functional lung status: the six minute walk test in chronic lung disease patients. Am J Respir Crit Care Med. 1997;155(4):1278-82.

9. Güell R, Casan P, Belda J, Sangenis M, Morante F, Guyatt $\mathrm{GH}$, et al. Long-term effects of outpatient rehabilitation of COPD: A randomized trial. Chest. 2000;117(4):976-83.

10. Murray JA, Waterman LA, Ward J, Baird JC, Mahler DA. Perceptual and physiologic responses during treadmill and cycle exercise in patients with COPD. Chest. 2009;135(2);384-90.

11. Carter H, Jones AM, Barstow TJ, Burnley M, Williams CA, Doust JH. Oxygen uptake kinetics in treadmill running and cycle ergometry: a comparison. J Appl Physiol. 2000;89(3):899-907.

12. Palange P, Forte S, Onorati P, Manfredi F, Serra P, Carlone S. Ventilatory and metabolic adaptations to walking and cycling in patients with COPD. J Appl Physiol. 2000;88(5):1715-20.

13. Sava F, Laviolette L, Bernard S, Breton MJ, Bourbeau J, Maltais F. The impact of obesity on walking and cycling performance and response to pulmonary rehabilitation in COPD. BMC Pulm Med. 2010;10:55.

14. Yuarsa TA, Yunus FA, Antariksa B. Korelasi penilaian kualitas hidup dan prognosis penderita PPOK dengan CAT, SGRQ dan BODE di RSP Jakarta. J Respir Indo. 2013;33:816. Indonesian.

15. Weatherall M, Marsh S, Shirtcliffe P, Williams M, Travers J, Beasley R. Quality of life measured by the St George's respiratory questionnaire and spirometry. Eur Respir J. 2009;33(5):1025-30.

16. Gold Committee. Global strategy for the diagnosis, management and prevention of COPD. Global initiative for chronic obstructive lung disease, 2010. p. 1-12.

17. Donner CF, Muir JF. Selection criteria and programmes for pulmonary rehabilitation in COPD patients. Eur Respir J. 1997;10:744-57.

18. Wijayakusuma D. Fisiologi pernapasan. Bagian Ilmu Faal Fakultas Kedokteran Universitas Indonesia: 1- 45. Indonesian. 